\title{
Open-chain and cyclic amidrazones forming persistent radicals. An electrochemical and quantum chemical study
}

\author{
Fabian Krauth, ${ }^{\mathrm{a} *}$ Rudolf Friedemann, ${ }^{\mathrm{b}}$ Hans-Hermann Rüttinger, ${ }^{\mathrm{a}}$ and Petra Frohberg ${ }^{\mathrm{a}}$ \\ ${ }^{a}$ Institute of Pharmacy, Martin-Luther-Universiy Halle-Wittenberg \\ Wolfgang-Langenbeck-Str. 4, D-06120 Halle, Germany \\ ${ }^{b}$ Institute of Chemistry, Martin-Luther-University Halle-Wittenberg, \\ Kurt-Mothes-Straße 2, D-06120 Halle, Germany \\ E-mail:_fabian.krauth@pharmazie.uni-halle.de
}

\begin{abstract}
The electrochemical oxidation of various open-chain and cyclic amidrazones in acetonitrile was investigated by cyclic voltammetry. The oxidation was found reversible for both $N^{2}$-disubstituted open-chain amidrazones and all cyclic compounds with the exception of triazole derivatives that could not be oxidized. Microcoulometry revealed an extrapolated charge consumption of one electron per molecule. The experimentally obtained oxidation potentials correlate well with the reaction energy of oxidation calculated from density function theory (DFT) that clearly supports the hypothesis of a persistent radical formation. The total atomic spin density of radical cations was calculated and permits to make a statement about the localization of radical formation. The synthesis of $(E)$-2-(methylphenyl)hydrazono- $N$-phenyl-2-piperidin-1-ylacetamide 7 representing open-chain $\alpha$-carbonyl substituted $N^{2}$-alkyl, aryl-amidrazones and the synthesis of 6-aminosubstituted 2,3,4,5-tetrahydro-1,2,4-triazin-5-ones, a new class of amidrazones, are described.
\end{abstract}

Keywords: Cyclic voltammetry, amidrazones, 1,2,4-triazin-5-ones, density function theory, persistent radicals

\section{Introduction}

Amidrazones 1 are known as convenient building blocks for various N-heterocycles, such as 4,5dihydro-1H-1,2,4-triazoles (triazolines) 2, 1H-1,2,4-triazoles 3, or benzotriazepines 4 (Scheme 1). ${ }^{1}$ In recent years, various biological activities have been discovered for amidrazone compounds, e.g., fungistatic ${ }^{2}$, bacteriostatic, and antimycotic ${ }^{3}$ activities as well as inhibitory effects on mammalian and plant enzymes, e.g. lipoxygenases $(\mathrm{LOX})^{4}$ that are possibly subject to a redox mechanism. 
The aim of our study is: (i) To evaluate the redox behavior of compounds that belong to different classes of amidrazones ${ }^{5}$ (Scheme 1, Tables 1-5) with structural and substituent variations; for this purpose, cyclic voltammetry in an aprotic medium was successfully applied. (ii) To gain further insight into the nature of the oxidation products we used density function theory (DFT) calculations on the B3LYP/6-31G(d) level ${ }^{6}$ that allows not only to localize the main spin density of the radical cation, but also provides information about geometrical changes of the molecule during the oxidation process. The results are expected to make a contribution to elucidate the amenability of amidrazone compounds for participation in redox processes and to make a first statement about the most likely mechanism of persistent amidrazone radical formation. ${ }^{7}$

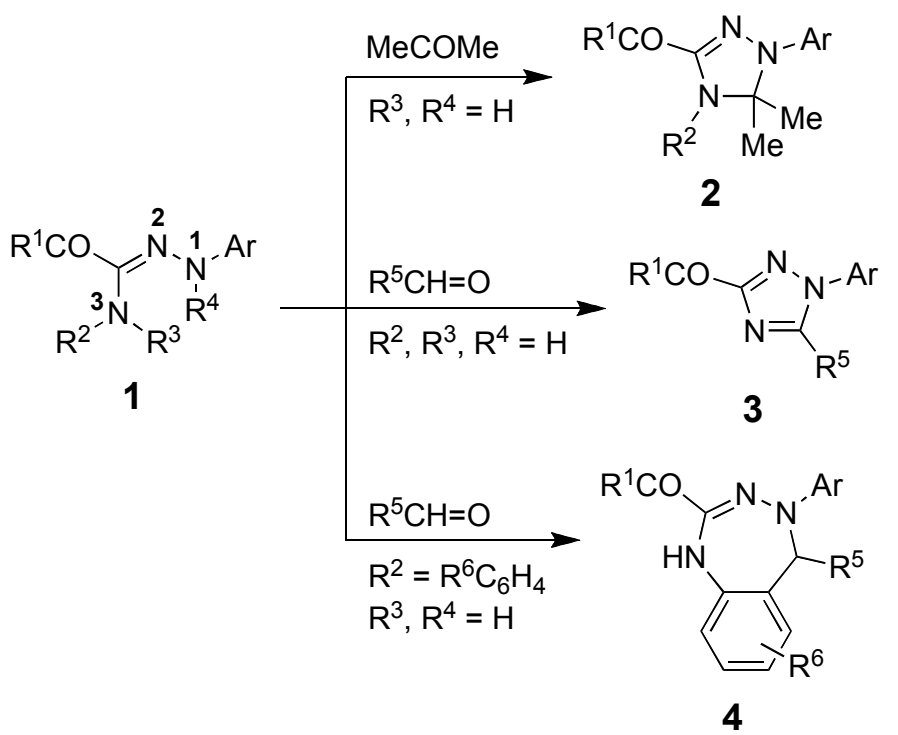

Scheme 1. IUPAC nomenclature numbers the distant nitrogen atoms of the amidrazone skeleton $\mathrm{N} 1-\mathrm{C}=\mathrm{N}-\mathrm{N} 2$ only. Contrary, we use the numbering as shown for $\mathbf{1}$ in order to apply consistent numbering as used in previous publications. ${ }^{5}$ For substituents in 1-4 see Table 1 and Tables $3-5$.

Additionally, we exemplify the synthesis of open-chain $\alpha$-carbonyl substituted $N^{2}$-alkyl, aryl-amidrazones and 6-amino-substituted 2,3,4,5-tetrahydro-1,2,4-triazin-5-ones as cyclic compounds with amidrazone scaffold. Substituents and oxidation potentials are presented in Tables 1-5. Cyclic voltammograms showing the formation of persistent radical cations are provided and results of quantum chemical calculations are related to the electrochemical data. 


\section{Results and Discussion}

\section{Synthesis}

Hydrazonoyl chlorides as starting compounds for N1-disubstituted open-chain amidrazones could not be prepared via the generally applied Japp-Klingemann cleavage. Therefore, an alternative synthetic pathway had to be explored. In the literature, a number of different strategies have been reported. ${ }^{8}$ For our purpose, (Z)- $N$-methyl- $N$-phenylhydrazonoyl chloride 6 was obtained by the reaction of oxanilide $N$-methyl- $N$-phenylhydrazide 5 with phosphorus pentachloride according to a reported procedure. ${ }^{9}$ The hydrazonoyl chloride $\mathbf{6}$ was subsequently converted into amidrazone 7 by the reaction with piperidine (Scheme 2).

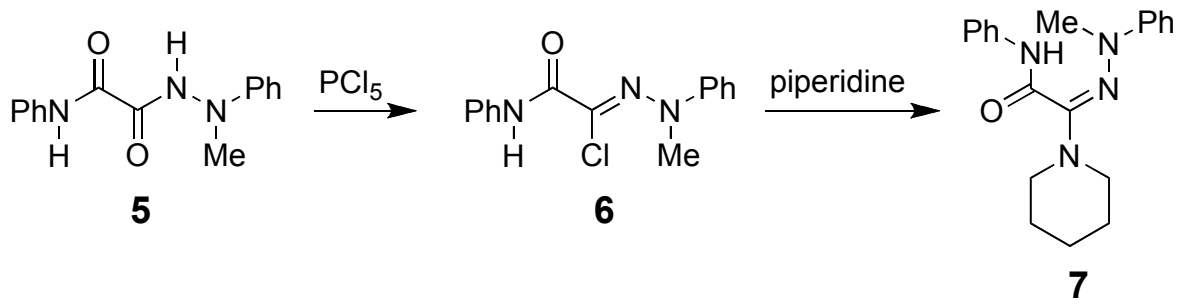

\section{Scheme 2}

Using NOE experiments, 7 was found to exist as $E$ isomer unlike the reported N1-monosubstituted amidrazones such as $\mathbf{1 i}^{5}$ (Scheme 3). Irradiation at the frequency of the methyl protons causes an $\mathrm{NOE}$ to $\mathrm{CONH}$ but not to $\mathrm{NCH}_{2}$ of the piperidine ring.

To investigate the mechanism of cyclization, which results in benzotriazepines, triazoles and triazolines, we chose not only N3-unsubstituted amidrazones as starting materials but also N3mono- and disubstituted amidrazone derivatives (Scheme 1, Table 1). Reaction of amidrazone 1i with formaldehyde in the presence of $p$-toluenesulfonic acid yielded a product which was identified as compound $\mathbf{8}$ (Scheme 3), the first member of a novel cyclic amidrazone class of 6amino-substituted 2,3,4,5-tetrahydro-1,2,4-triazin-5-ones.

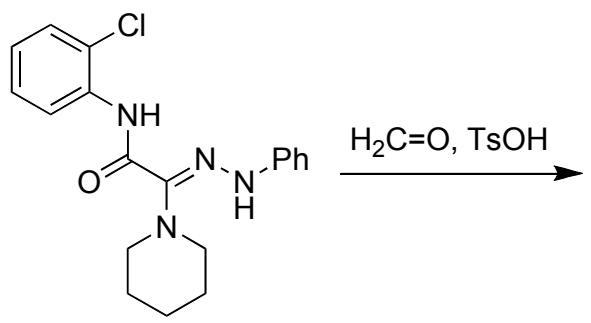

$1 \mathrm{i}$<smiles>O=C1C(N2CCCCC2)=NN(c2ccccc2)CN1c1ccccc1Cl</smiles>

8

\section{Scheme 3}


In the NMR spectra, a long-range coupling was observed between both protons in position 3 of the triazinone ring and the aromatic carbons directly bonded to the nitrogen atoms in triazinone positions 2 and 4. Electron impact mass spectrometry (EI-MS) and results of elemental analysis confirm the constitution of this structure.

\section{Electrochemistry}

Owing to their hydrazone structure, all amidrazones are susceptible to oxidation. Some of these species having a very low oxidation potential, such as $(E)-\mathbf{1 p}$ or $(E)$-1q (Table 2), are readily oxidized in diluted solutions (in DMF, $\mathrm{MeOH}$ or $\mathrm{MeCN}$ ) as soon as they are exposed to air. This autoxidation process results in highly colored solutions from the original colorless compounds, and in most cases hydrogen peroxide can be found as reduction product of molecular oxygen. In order to gain further insight into the oxidation process we determined the electrochemical oxidation potentials of all the amidrazones comprised in Tables $1-5$ by cyclic voltammetry at a platinum microelectrode. To avoid complications by reactions prior to electrochemical oxidation and immediate decomposition of the oxidation products, acetonitrile was used as an inert solvent.

Table 1. Oxidation potentials of open-chain N1-monosubstituted amidrazones (Z)-1a-o

\begin{tabular}{|c|c|c|c|c|}
\hline | & $\mathrm{R}^{1}$ & $\mathrm{Ar}$ & $\mathrm{R}^{2} / \mathrm{R}^{3}$ & Oxidation potential $^{a}$ \\
\hline $1 \mathbf{a}^{b}$ & $\mathrm{PhNH}$ & $\mathrm{Ph}$ & $\mathrm{H} / \mathrm{H}$ & $740 \mathrm{mV}$ \\
\hline $1 b$ & $\mathrm{PhNH}$ & $\mathrm{Ph}$ & $\mathrm{CH}_{3} / \mathrm{H}$ & $560 \mathrm{mV}$ \\
\hline 1c & $\mathrm{PhNH}$ & $\mathrm{Ph}$ & $\mathrm{Ph} / \mathrm{H}$ & $790 \mathrm{mV}$ \\
\hline 1d & $\mathrm{PhNH}$ & $3-\mathrm{FC}_{6} \mathrm{H}_{4}$ & $\mathrm{H} / \mathrm{H}$ & $840 \mathrm{mV}$ \\
\hline $1 \mathrm{e}$ & $\mathrm{PhNH}$ & $4-\mathrm{CH}_{3} \mathrm{C}_{6} \mathrm{H}_{4}$ & $\mathrm{CH}_{3} / \mathrm{H}$ & $520 \mathrm{mV}$ \\
\hline 1f & $\mathrm{PhNH}$ & $4-\mathrm{ClC}_{6} \mathrm{H}_{4}$ & $\mathrm{CH}_{3} / \mathrm{H}$ & $600 \mathrm{mV}$ \\
\hline $1 g$ & $2-\mathrm{ClC}_{6} \mathrm{H}_{4} \mathrm{NH}$ & $\mathrm{Ph}$ & $\mathrm{CH}_{3} / \mathrm{CH}_{3}$ & $710 \mathrm{mV}$ \\
\hline $1 \mathrm{~h}$ & $2-\mathrm{ClC}_{6} \mathrm{H}_{4} \mathrm{NH}$ & $\mathrm{Ph}$ & $4-\mathrm{ClC}_{6} \mathrm{H}_{4} / \mathrm{H}$ & $880 \mathrm{mV}$ \\
\hline $\mathbf{1 i}$ & $2-\mathrm{ClC}_{6} \mathrm{H}_{4} \mathrm{NH}$ & $\mathrm{Ph}$ & $\left(\mathrm{CH}_{2}\right)_{5}$ & $720 \mathrm{mV}$ \\
\hline $\mathbf{1 j}$ & $2-\mathrm{ClC}_{6} \mathrm{H}_{4} \mathrm{NH}$ & $2-\mathrm{ClC}_{6} \mathrm{H}_{4}$ & $\mathrm{H} / \mathrm{H}$ & $800 \mathrm{mV}$ \\
\hline $1 \mathrm{k}$ & $2-\mathrm{ClC}_{6} \mathrm{H}_{4} \mathrm{NH}$ & $3-\mathrm{ClC}_{6} \mathrm{H}_{4}$ & $\mathrm{CH}_{3} / \mathrm{CH}_{3}$ & $720 \mathrm{mV}$ \\
\hline 11 & $3-\mathrm{ClC}_{6} \mathrm{H}_{4} \mathrm{NH}$ & $3-\mathrm{ClC}_{6} \mathrm{H}_{4}$ & $\mathrm{H} / \mathrm{H}$ & $730 \mathrm{mV}$ \\
\hline $1 \mathrm{~m}$ & $4-\mathrm{FC}_{6} \mathrm{H}_{4} \mathrm{NH}$ & $3-\mathrm{CH}_{3} \mathrm{COC}_{6} \mathrm{H}_{4}$ & $\mathrm{H} / \mathrm{H}$ & $680 \mathrm{mV}$ \\
\hline 1n & $\mathrm{CH}_{3} \mathrm{CH}_{2} \mathrm{O}$ & $4-\mathrm{ClC}_{6} \mathrm{H}_{4}$ & $\mathrm{H} / \mathrm{H}$ & $760 \mathrm{mV}$ \\
\hline 10 & $\mathrm{CH}_{3} \mathrm{OCO}\left(\mathrm{CH}_{2}\right)_{3}$ & $\mathrm{Ph}$ & $\mathrm{Ph} / \mathrm{H}$ & $900 \mathrm{mV}$ \\
\hline
\end{tabular}

${ }^{a}$ Electrochemical oxidation of all compounds $\mathbf{1 a}-\mathbf{o}$ was irreversible. ${ }^{b}$ Available as hydrochloride. 
Table 2. Oxidation potentials of N1-monosubstituted reference amidrazones 1p, 1q, and N1disubstituted amidrazone 7

\begin{tabular}{|c|c|c|c|c|}
\hline $\mathrm{R}$ & $\mathrm{R}^{1}$ & $\mathrm{Ar}$ & $\mathrm{R}^{4}$ & oxidation potential $^{a}$ \\
\hline$(Z)-\mathbf{1 p}$ & $\mathrm{PhNH}$ & $\mathrm{Ph}$ & $\mathrm{H}$ & $720 \mathrm{mV}$ \\
\hline$(E)-\mathbf{1 p}$ & $\mathrm{PhNH}$ & $\mathrm{Ph}$ & $\mathrm{H}$ & $470 \mathrm{mV}$ \\
\hline$(E)-\mathbf{1} \mathbf{q}^{b}$ & $\left(\mathrm{CH}_{3}\right)_{2} \mathrm{~N}$ & 4- $\mathrm{CH}_{3} \mathrm{C}_{6} \mathrm{H}_{4}$ & $\mathrm{H}$ & $330 \mathrm{mV}$ \\
\hline$(E)-7$ & $\mathrm{PhNH}$ & $\mathrm{Ph}$ & $\mathrm{CH}_{3}$ & $580 \mathrm{mV}$ \\
\hline
\end{tabular}

${ }^{a}$ Electrochemical oxidation of $\mathbf{1 p}$ and $\mathbf{1 q}$ was irreversible, $\mathbf{7}$ reversible. ${ }^{b}(Z)-\mathbf{1 q}$ could not be prepared.

Table 3. Oxidation potentials of the triazolines $2 \mathbf{a}-\mathbf{i}$

\begin{tabular}{|c|c|c|c|c|}
\hline Compound & $\mathrm{R}^{1}$ & $\mathrm{Ar}$ & $\mathrm{R}^{2}$ & Oxidation potential ${ }^{a}$ \\
\hline $2 \mathbf{a}$ & $\mathrm{PhNH}$ & $\mathrm{Ph}$ & $\mathrm{H}$ & $640 \mathrm{mV}$ \\
\hline $2 \mathbf{b}$ & $\mathrm{PhNH}$ & $\mathrm{Ph}$ & $\mathrm{CH}_{3}$ & $570 \mathrm{mV}$ \\
\hline $2 \mathrm{c}$ & $\mathrm{PhNH}$ & $3-\mathrm{FC}_{6} \mathrm{H}_{4}$ & $\mathrm{H}$ & $730 \mathrm{mV}$ \\
\hline 2d & $\mathrm{PhNH}$ & 4- $\mathrm{CH}_{3} \mathrm{C}_{6} \mathrm{H}_{4}$ & $\mathrm{CH}_{3}$ & $490 \mathrm{mV}$ \\
\hline $2 \mathrm{e}$ & $\mathrm{PhNH}$ & $4-\mathrm{ClC}_{6} \mathrm{H}_{4}$ & $\mathrm{CH}_{3}$ & $580 \mathrm{mV}$ \\
\hline $2 f$ & $2-\mathrm{ClC}_{6} \mathrm{H}_{4} \mathrm{NH}$ & $\mathrm{Ph}$ & $\mathrm{H}$ & $630 \mathrm{mV}$ \\
\hline $2 g$ & $2-\mathrm{ClC}_{6} \mathrm{H}_{4} \mathrm{NH}$ & $3-\mathrm{ClC}_{6} \mathrm{H}_{4}$ & $\mathrm{H}$ & $770 \mathrm{mV}$ \\
\hline $2 \mathrm{~h}$ & $3-\mathrm{ClC}_{6} \mathrm{H}_{4} \mathrm{NH}$ & $3-\mathrm{ClC}_{6} \mathrm{H}_{4}$ & $\mathrm{H}$ & $730 \mathrm{mV}$ \\
\hline $2 \mathbf{i}$ & $4-\mathrm{FC}_{6} \mathrm{H}_{4} \mathrm{NH}$ & $3-\mathrm{CH}_{3} \mathrm{COC}_{6} \mathrm{H}_{4}$ & $\mathrm{H}$ & $680 \mathrm{mV}$ \\
\hline
\end{tabular}

${ }^{a}$ Electrochemical oxidation of all compounds $\mathbf{2 a}-\mathbf{i}$ was reversible.

Table 4. Oxidation potentials of triazoles 3a-c

\begin{tabular}{ccccc}
\hline Compound & $\mathrm{R}^{1}$ & $\mathrm{Ar}$ & $\mathrm{R}^{5}$ & Oxidation potential $^{a}$ \\
\hline $\mathbf{3 a}$ & $2-\mathrm{ClC}_{6} \mathrm{H}_{4} \mathrm{NH}$ & $2-\mathrm{ClC}_{6} \mathrm{H}_{4}$ & $\mathrm{H}$ & - \\
$\mathbf{3 b}$ & $\mathrm{CH}_{3} \mathrm{CH}_{2} \mathrm{O}$ & $4-\mathrm{ClC}_{6} \mathrm{H}_{4}$ & $\mathrm{H}$ & - \\
$\mathbf{3 c}$ & $\mathrm{CH}_{3} \mathrm{CH}_{2} \mathrm{O}$ & $4-\mathrm{ClC}_{6} \mathrm{H}_{4}$ & $\mathrm{CH}_{3}$ & - \\
\hline
\end{tabular}

${ }^{a}$ Triazoles 3a-c were not amenable for electrochemical oxidation. 
Table 5. Oxidation potentials of the benzotriazepines $\mathbf{4 a - h}$

\begin{tabular}{clllll}
\hline \multirow{2}{*}{ Compound } & \multicolumn{1}{c}{$\mathrm{R}^{1}$} & \multicolumn{2}{c}{$\mathrm{Ar}$} & $\mathrm{R}^{5}$ & \multicolumn{2}{c}{$\mathrm{R}^{6}$} & Oxidation potential $^{a}$ \\
\hline $\mathbf{4 a}$ & $\mathrm{PhNH}$ & $\mathrm{Ph}$ & $\mathrm{Ph}$ & - & $710 \mathrm{mV}$ \\
$\mathbf{4 b}$ & $2-\mathrm{Cl}-\mathrm{C}_{6} \mathrm{H}_{4} \mathrm{NH}$ & $\mathrm{Ph}$ & $\mathrm{H}$ & $7-\mathrm{Cl}$ & $770 \mathrm{mV}$ \\
$\mathbf{4 c}$ & $\mathrm{CH}_{3} \mathrm{OCO}\left(\mathrm{CH}_{2}\right)_{3}$ & $\mathrm{Ph}$ & $\mathrm{H}$ & - & $690 \mathrm{mV}$ \\
$\mathbf{4 d}$ & $\mathrm{CH}_{3} \mathrm{OCO}\left(\mathrm{CH}_{2}\right)_{3}$ & $\mathrm{Ph}$ & $\mathrm{Ph}$ & - & $750 \mathrm{mV}$ \\
$\mathbf{4 e}$ & $\mathrm{CH}_{3} \mathrm{OCO}\left(\mathrm{CH}_{2}\right)_{3}$ & $\mathrm{Ph}$ & $\mathrm{H}$ & $9-\mathrm{CH}_{2} \mathrm{OH}$ & $670 \mathrm{mV}$ \\
$\mathbf{4 f}$ & $\mathrm{CH}_{3} \mathrm{OCO}\left(\mathrm{CH}_{2}\right)_{3}$ & $\mathrm{Ph}$ & $\mathrm{H}$ & $7-\mathrm{Cl}$ & $730 \mathrm{mV}$ \\
$\mathbf{4 g}$ & $\mathrm{CH}_{3} \mathrm{OCO}\left(\mathrm{CH}_{2}\right)_{3}$ & $4-\mathrm{ClC}_{6} \mathrm{H}_{4}$ & $\mathrm{H}$ & - & $740 \mathrm{mV}$ \\
$\mathbf{4 h}$ & $\mathrm{CH}_{3} \mathrm{OCO}\left(\mathrm{CH}_{2}\right)_{3}$ & $4-\mathrm{ClC}_{6} \mathrm{H}_{4}$ & $\mathrm{H}$ & $7-\mathrm{Cl}$ & $800 \mathrm{mV}$ \\
\hline
\end{tabular}

${ }^{a}$ Electrochemical oxidation of all compounds $\mathbf{4 a - h}$ was reversible.

The potentials were measured against a saturated $\mathrm{Ag} / \mathrm{AgCl}$ reference electrode and corrected in reference to the oxidation potential of ferrocene. Open chain as well as cyclic amidrazones can be oxidized between 300 and $800 \mathrm{mV}$ at the platinum electrode as shown exemplarily in Tables 1-3 and 5. Compound 8 (not mentioned in Tables 1-5 exhibits an oxidation potential of $658 \mathrm{mV}$. The aromatic triazoles $\mathbf{3 a}-\mathbf{c}$ (Table 4) demonstrated stability against electrochemical oxidation up to the limit of $1300 \mathrm{mV}$. Generally, the substitution pattern of the aromatic group (Ar) was recognized as an important structural aspect for the oxidation potential in all of the tested compound classes. Exemplified for the triazolines, it is apparent that electron withdrawing or rather electron releasing groups influence the potential to be oxidized. Substituents containing strong negative inductive effects, e.g., fluorine 2c or chlorine $\mathbf{2 e}$ atoms raise the required oxidation potential whereas unsubstituted $\mathbf{2 b}$ or methylsubstituted 2d phenyl groups support lower oxidation potentials. The voltammograms at the microelectrode show a typical sigmoid shape (see Figure 1) attributed to the special diffusion conditions at microelectrodes. Analysis gives a hint to a diffusion controlled one-electron step. This is confirmed by microcoulometry (see below). Open-chain amidrazones, which tend to form $E / Z$ isomers, can additionally be qualitatively checked for impurities with the respective other isomer by cyclic voltammetry at a platinum microelectrode (Figure 1). 


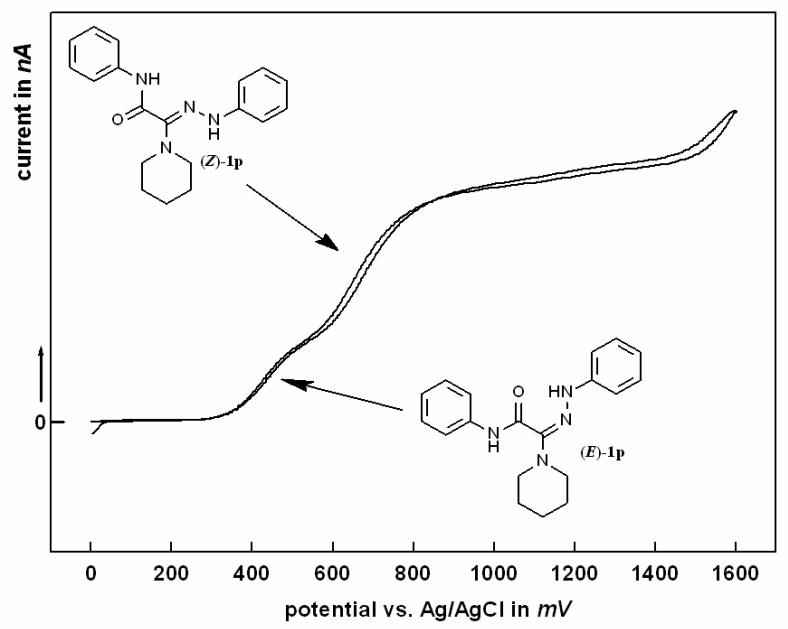

Figure 1. Cyclic voltammogram of 1p [(Z:E) 2:1]; scan rate of $40 \mathrm{mV} \mathrm{s}^{-1}$ at a $\mathrm{Pt}$ microelectrode (d: $0.01 \mathrm{~mm})$.
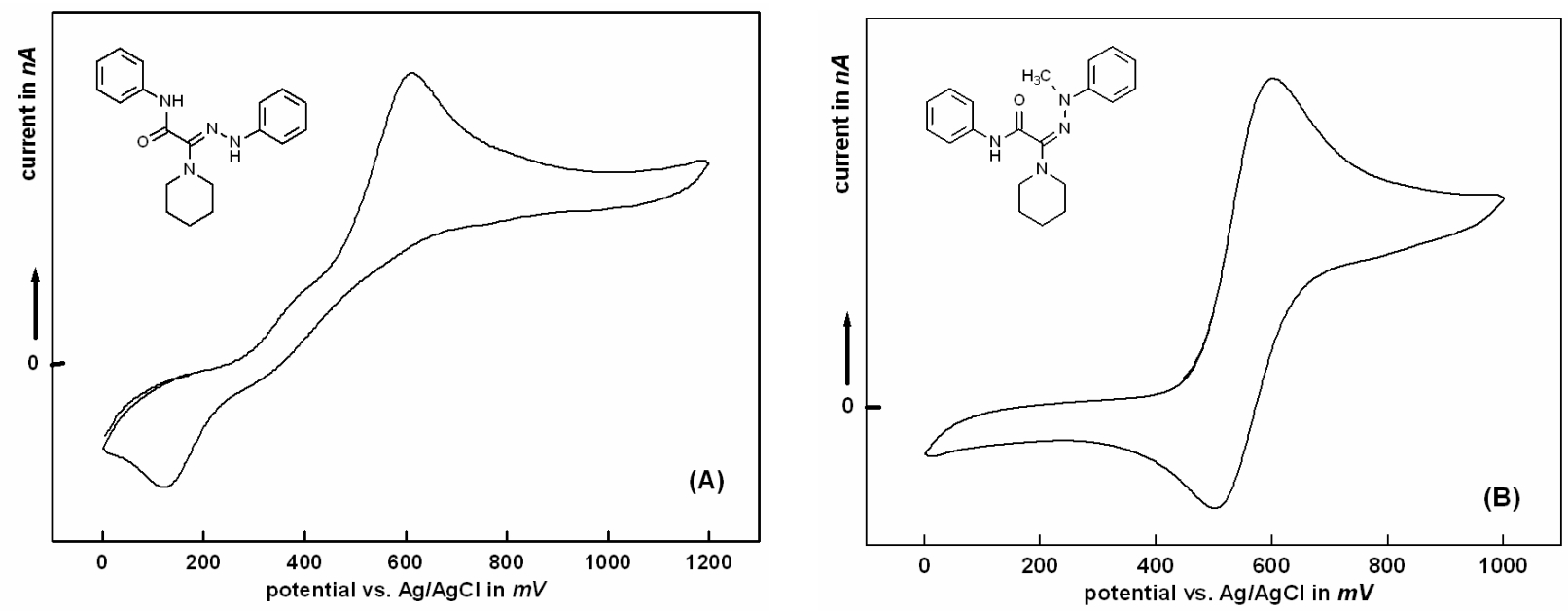

Figure 2. Cyclic voltammograms of $(Z)-\mathbf{1 p}(\mathrm{A})$ and $(E)-7(\mathrm{~B})$ at a Pt macroelectrode (d: 0.15 $\mathrm{mm})$ at a scan rate of $40 \mathrm{mV} \mathrm{s}^{-1}$.

Both isomers $(E)-\mathbf{1 p}$ and $(Z)-\mathbf{1 p}$ exhibit a characteristic curve for an irreversible redox process at the macroelectrode like the other open-chain amidrazones with monosubstituted N1 $\left(\mathrm{R}^{4}=\mathrm{H}\right)$ (Figure 2A, $(E)-1$ p not shown). Substitution of the N1-bonded hydrogen with e.g., a methyl group like in compound 7 leads to the appearance of a reversible intermediate radical species, as is readily evident from the shape of the cyclic voltammogram (Figure 2B) which correlates well with that of ferrocene. This radical state was found to be persistent for at least six repeated cyclovoltametric runs and beyond.

Similarly, the radical species of the triazolines, benzotriazepines and the novel triazinone compound $\mathbf{8}$ demonstrate a remarkable stability. The reversible behavior is shown for compound $\mathbf{2 b}$ (Figure $3 \mathrm{~A}$ ) as an example for a triazoline and compound $\mathbf{8}$ (Figure 3B). 

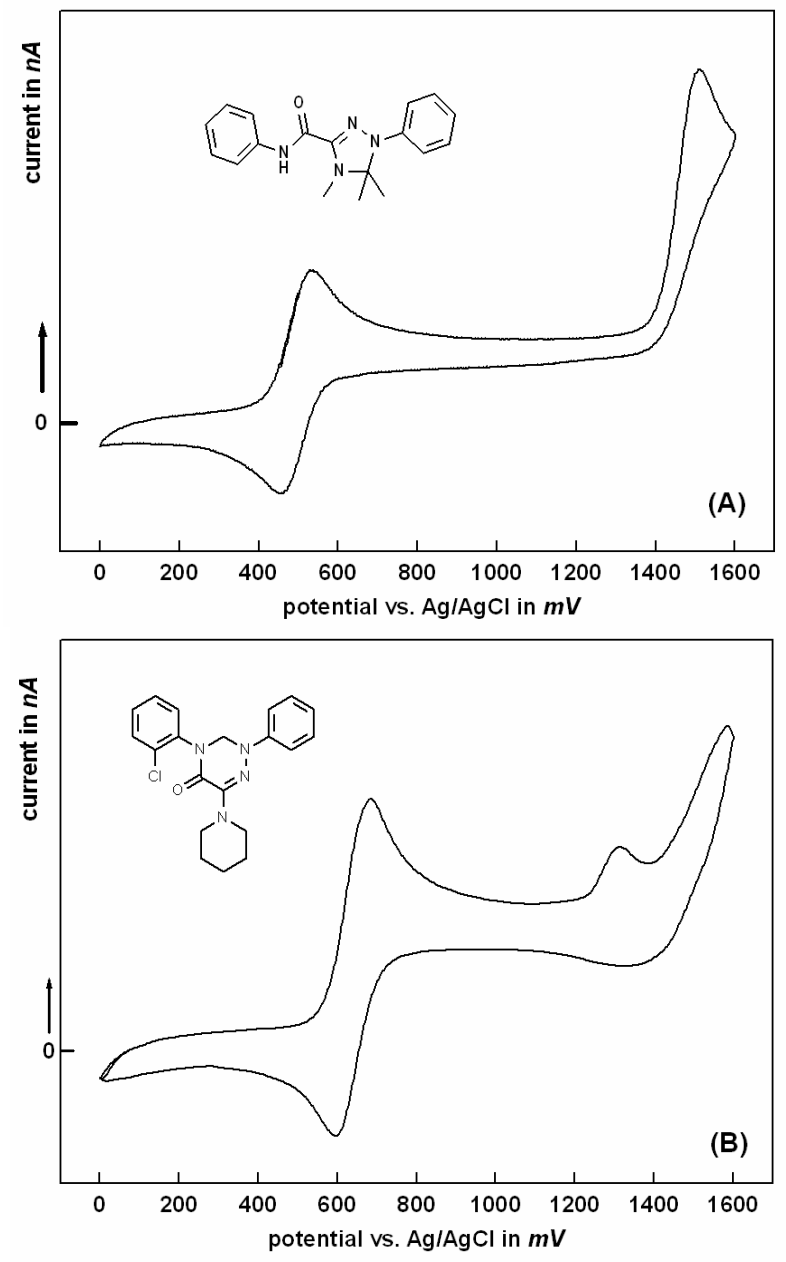

Figure 3. Cyclic voltammograms of $\mathbf{2 b}(\mathrm{A})$ and $\mathbf{8}(\mathrm{B})$ at a $\mathrm{Pt}$ macroelectrode (d: $0.15 \mathrm{~mm})$ at a scan rate of $40 \mathrm{mV} \mathrm{s}^{-1}$.

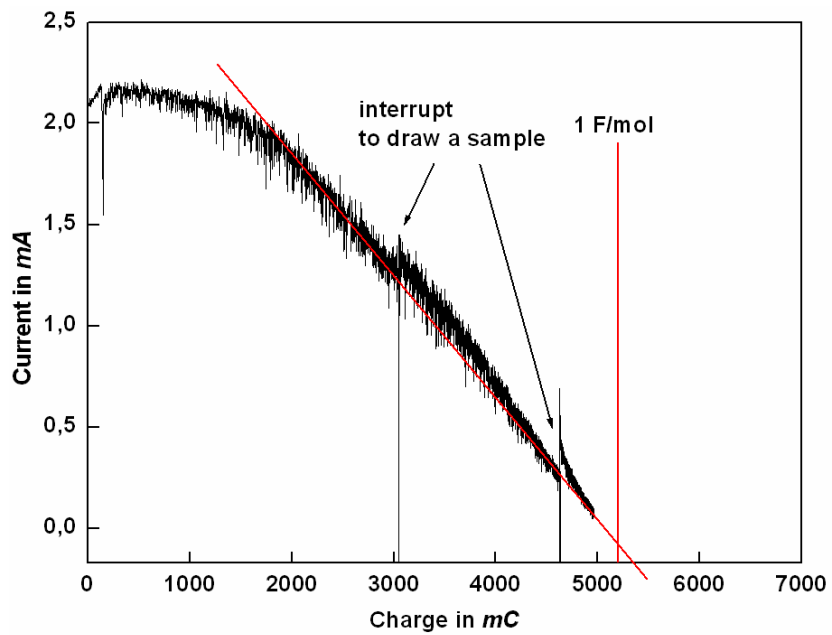

Figure 4. Preparative scale electrolysis of a solution containing $54 \mu \mathrm{M}$ of $\mathbf{2 d}$. 
Extrapolation of the electrolysis current results in a charge of $5.33 \mathrm{C}$ corresponding to 1.02 electrons per molecule. The deviation of the current from linearity at the beginning of the electrolysis is attributed to the ohmic drop in the cell and does not compromise the result.

Microcoulometric oxidation of $\mathbf{2 d}$ at a platinum sheet as the working electrode at 700 $\mathrm{mV}$ resulted in an extrapolated charge consumption of just one electron/molecule and yielded a stable deep green-blue colored solution that could be reduced at $-200 \mathrm{mV}$ to the starting compound (Figure 4). EPR spectra of the oxidized amidrazones clearly identify the product as a radical, however the spectra showed no fine structure, hence no information on the spin distribution could be obtained (data not shown). For gaining insight into the structures of the reaction products we used quantum chemical calculations.

\section{Quantum chemical studies}

Density functional theory (DFT) calculations on the B3LYP/6-31G(d) level were performed on amidrazones and their radical cations to study structure-property relationships within the oxidation process of such compounds. The investigations were carried out on the isolated systems using the GAUSSIAN98 program package. ${ }^{6}$ The energetically preferred conformations of the neutral molecules and the radical cations were obtained by full optimization. The structures of the minima were characterized by frequency calculations on the same level. For molecules with an open amidrazone structure the possible $E$ and $Z$ isomers related to the $\mathrm{C} 1-\mathrm{N} 2$ double bond (for numbering see Figure 6) were taken as alternative starting structures to find the most stable conformers. Both amidrazones with a mono- and disubstituted N1 atom were considered as they show differences in their electrochemical oxidation behavior. The reaction energy $\Delta \mathrm{E}$ of the amidrazones for the oxidation in the gas phase $\mathrm{A} \rightarrow \mathrm{A}^{\bullet+}+\mathrm{e}^{-}$was calculated. The obtained $\Delta \mathrm{E}$ values were correlated with electrochemically measured oxidation potentials $\mathrm{E}_{\mathrm{ox}}$. In the electrochemical measurements the same solvent and similar conditions were used. Therefore, the measured $\mathrm{E}_{\mathrm{ox}}$ data and the calculated $\Delta \mathrm{E}$ values can be compared in some way. Within the more qualitative considerations we have not included thermal corrections and solvation effects. Moreover, the energy of the highest occupied molecular orbital $\varepsilon_{\mathrm{HOMO}}$ for the amidrazones was considered. The results are shown in Table 6. Amidrazones are classified with respect to the substitution at the $\mathrm{N} 1$ atom. The first part contains disubstituted compounds and the second part the monosubstituted ones. 
Table 6. Calculated DFT reaction energies $(\Delta \mathrm{E})$, orbital energies $\left(\varepsilon_{\mathrm{HOMO}}\right)$ and electrochemically measured oxidation potentials $\left(\mathrm{E}_{\mathrm{ox}}\right)$ for some amidrazones including $(E)$ and $(Z)$ isomers

\begin{tabular}{rlll}
\hline Compound & $\Delta \mathrm{E}(\mathrm{kJ} / \mathrm{mol})^{a}$ & $\varepsilon_{\mathrm{HOMO}}(\mathrm{eV})^{b}$ & $\mathrm{E}_{\mathrm{ox}}(\mathrm{mV})^{c}$ \\
\hline$(E)-\mathbf{7}$ & 570 & -4.82 & 580 \\
$\mathbf{2 b}$ & 549 & -4.95 & 570 \\
$\mathbf{4 c}$ & 606 & -5.06 & 690 \\
$\mathbf{3 c}$ & 782 & -6.75 & - \\
$\mathbf{8}$ & 579 & -4.99 & 660 \\
$(E)-\mathbf{1 p}$ & 585 & -5.05 & 470 \\
$(Z)-\mathbf{1 p}$ & 588 & -5.35 & 720 \\
$(E)-\mathbf{1 q}$ & 553 & -4.67 & 330 \\
\hline
\end{tabular}

${ }^{a}$ Reaction energy for the formation of the radical cation $\mathrm{A} \rightarrow \mathrm{A}^{\cdot+}+\mathrm{e}^{-} \cdot{ }^{b}$ Energy of the highest occupied molecular orbital in the neutral molecule. ${ }^{c}$ Electrochemically measured oxidation potential for the oxidation process.

A correlation of the reaction energies $\Delta \mathrm{E}$ with the oxidation potentials $\mathrm{E}_{\text {ox }}$ indicates that a certain relationship can only be found within the disubstituted compounds. This is illustrated in Figure 5. The calculated values for the compound 3c (Table 6) are in qualitative agreement with the experimental findings of the difficult oxidability of such substances. The compounds with an N1-H bond (marked $\times$ ) in Figure 5 show significant deviations from the linear fit obtained by the systems with two substituents at the $\mathrm{N} 1$ atom. The results support the electrochemical findings that the presence of an N1-H function in the amidrazones causes an irreversible pathway of the oxidation process. Obviously, amidrazones with a N1-H bond show a more complex mechanism in the radical oxidation reaction.

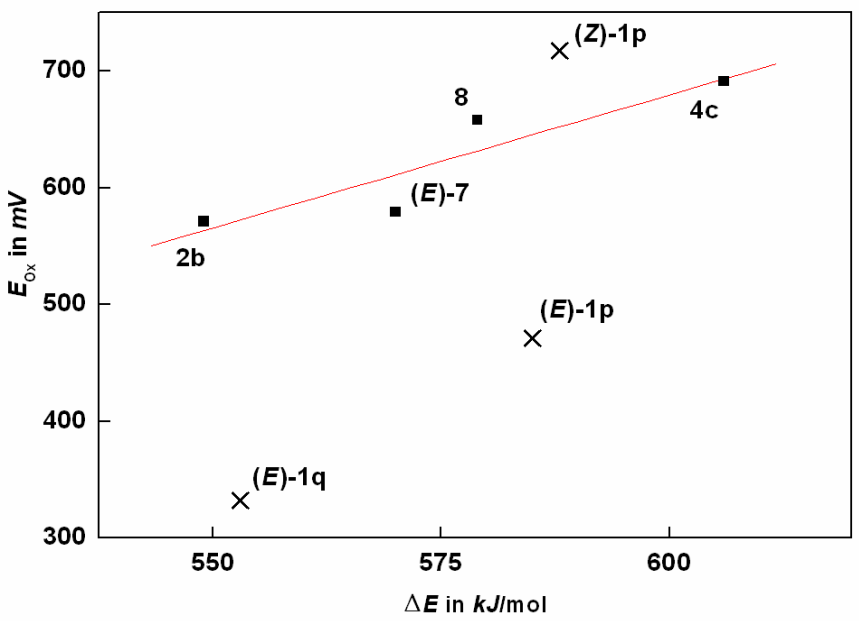

Figure 5. Correlation between oxidationpotentials $\mathrm{E}_{\mathrm{ox}}$ and calculated reactionenergies. $\Delta \mathrm{E}$ for the formation of theradical cations of disubstitutedcompounds $\mathbf{2 b}, \mathbf{4 c},(E)-\mathbf{7}, \mathbf{8}$ ( $\mathbf{\square})$; 
$\mathrm{y}=-687.25+2.28 \mathrm{x} ; \mathrm{r}=0.9105$. Monosubstituted compounds $(E)-\mathbf{1} \mathbf{p},(Z)-\mathbf{1 p}$, and $(E)-\mathbf{1 q}(\times)$ showsignificant deviations from linear fit.

A comparison of the most stable conformers of the molecule and the corresponding radical cation indicates significant structural changes between the starting compound and the product of the oxidation reaction. This can be deduced from the energetically preferred structures of $(E)-\mathbf{1 p}$ and its radical cation given in Figure 6. The molecular segments at the central $\mathrm{C} 1$ atom show a different arrangement in both species. It is remarkable that the formation of the radical cation causes a balance in the bond lengths of the amidrazone skeleton. Generally, in the radical cation the $\mathrm{C} 1-\mathrm{N} 2$ bond is lenghtened and the $\mathrm{C} 1-\mathrm{N} 3$ bond is shortened in comparison to the corresponding neutral molecule. It is noteworthy that the bond lengths of the amidrazone skeleton for all of the calculated molecules are within the range, which was found in other amidrazone derivatives by X-ray measurements (1.30-1.37 $\AA$ for $\mathrm{N} 1-\mathrm{N} 2,1.28-1.30 \AA$ for $\mathrm{C} 1-\mathrm{N} 2$ and $1.36-1.47 \AA$ for $\mathrm{C} 1-\mathrm{C} 3) .{ }^{4,5}$

Intramolecular hydrogen bonds are relevant both in the most stable conformers of the amidrazones and their radicals but especially in the systems with an $\mathrm{N} 1-\mathrm{H}$ bond. It should be mentioned that there is no correlation between $\varepsilon_{\text {Hомо }}$ and $\mathrm{E}_{\text {ox }}$ values (Table 6). The significant conformational changes between the molecule and its radical cation could be a main reason for these findings because this effect is not considered by the simple orbital correlation.

Conformational studies on the amidrazones including $E$ and $Z$ forms show that for the isolated molecules the $E$ isomer is more stable than the $Z$ isomer (systems $\mathbf{7}$ and $\mathbf{1 p}$ ) or has comparable stability (system 1q). This is quantified by the values of the relative energies $E_{\mathrm{r}}$ of the $Z$ isomers related to their $E$ isomers $\left(\mathrm{E}_{\mathrm{r}}=27 \mathrm{~kJ} / \mathrm{mol}\right.$ for $(Z)-7, \mathrm{E}_{\mathrm{r}}=34 \mathrm{~kJ} / \mathrm{mol}$ for $(Z)$ $1 \mathbf{p}$ and $\mathrm{E}_{\mathrm{r}}=0 \mathrm{~kJ} / \mathrm{mol}$ for $\left.(Z)-\mathbf{1 q}\right)$. X-ray investigations of amidrazone derivatives sometimes reveal $E$ and $Z$ isomers in the crystal. ${ }^{5}$

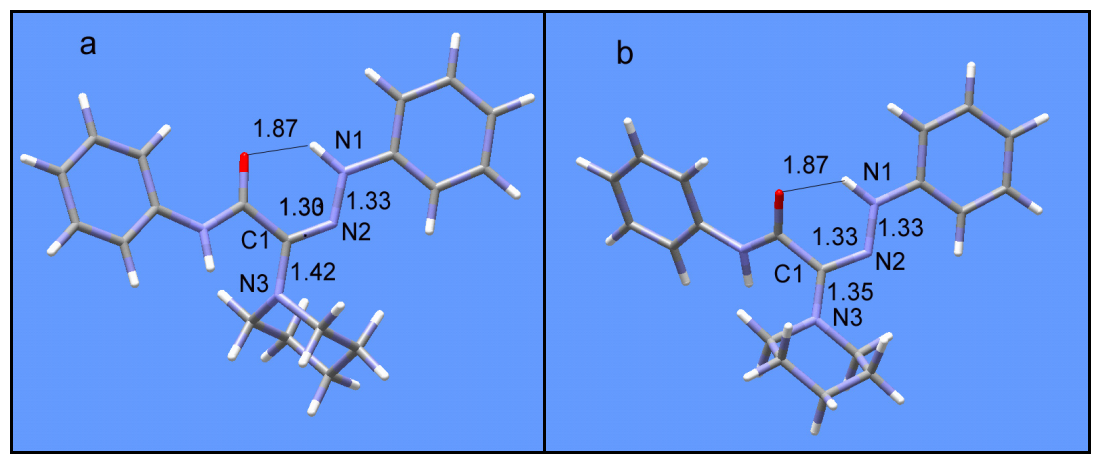

Figure 6. Calculated models of most stable structures and significant bond lengths for $(E)-\mathbf{1 p}$ (a: neutral molecule; b: radical cation). 
Moreover, the total atomic spin densities were calculated for the most stable conformers of the radical cations. It is notable that the dominant contributions were obtained at the nitrogen atoms of the amidrazone skeleton. The values at the other atoms including the $\mathrm{C} 1$ atom are significantly smaller. This is illustrated in Table 7.

Table 7. Significant DFT spin densities on the radical cations of amidrazones

\begin{tabular}{rcccc}
\hline Compound & $\mathrm{N} 1$ & $\mathrm{C} 1$ & $\mathrm{~N} 2$ & $\mathrm{~N} 3$ \\
\hline$(E)-\mathbf{7}$ & 0.419 & 0.035 & 0.133 & 0.142 \\
$\mathbf{2 b}$ & 0.351 & 0.031 & 0.143 & 0.162 \\
$\mathbf{4 c}$ & 0.379 & 0.029 & 0.102 & 0.158 \\
$\mathbf{8}$ & 0.348 & 0.0 & 0.172 & 0.260 \\
$(E)-\mathbf{1 p}$ & 0.366 & 0.045 & 0.107 & 0.214 \\
$(Z)-\mathbf{1 p}$ & 0.315 & 0.029 & 0.119 & 0.166 \\
$(E)-\mathbf{1 q}$ & 0.363 & 0.033 & 0.141 & 0.177 \\
\hline
\end{tabular}

In all cases the largest value for the total atomic spin density was found at the N1 atom, which is directly bound to the phenyl ring and most likely is the point of the radical origin. The values at the $\mathrm{N} 2$ and $\mathrm{N} 3$ atoms are comparable to a large extent excluding the radical cations of $\mathbf{8}$ and $(E)-\mathbf{1 p}$. For the $E$ and $Z$ isomers of 1 p no remarkable change in the atomic spin density distribution was found.

\section{Experimental Section}

General Procedures. Melting points were determined on a Boetius hot-stage apparatus. NMR spectra were recorded on a Gemini 2000 and Gemini 200, operating at $399.96 \mathrm{MHz}$ and 199.95 $\mathrm{MHz}$ for ${ }^{1} \mathrm{H}$ NMR and at 100.6 MHz and 50.3 MHz for ${ }^{13} \mathrm{C}$ NMR spectra. TMS was used as internal standard. Chemical shifts are given in $\delta$ units and refer to the centre of the signal. Mass spectra were obtained with an AMD 402 of the firm AMD INTEDRA (70 eV). Reactions were monitored by TLC (silica gel $60 \mathrm{~F}_{254}$, Merck) in chloroform/ether $(7: 3, \mathrm{v} / \mathrm{v})$ and detected with ultraviolet light (254 nm).

Amidrazones 1a-m, 1o- $\mathbf{q}$, triazolines $\mathbf{2 a}-\mathbf{i}$, triazole 3a, and benzotriazepines $\mathbf{4 a}-\mathbf{h}$ were prepared, purified and characterized as described previously.,

(Z)-Ethyl 2-amino-2-[2-(4-chlorophenyl)hydrazono]acetate (1n). A solution of 2-ethoxy-2oxoethane- $N$-(4-chlorophenyl)hydrazonoyl chloride $(2.6 \mathrm{~g}, 10 \mathrm{mmol})$ in dioxane $(\sim 40 \mathrm{~mL})$ was added dropwise to $7 \mathrm{~N}$ methanolic solution of ammonia $(3.6 \mathrm{~mL}, 25 \mathrm{mmol})$. After stirring at 35 ${ }^{\circ} \mathrm{C}$ for at least $12 \mathrm{~h}$ the mixture was poured in cold water $(150 \mathrm{~mL})$. The solid was collected, 
washed with water and dried. Recrystallization from chloroform/heptane gave pale yellow fine needles 1n (1.4 g, 71\%); mp 148-151 ${ }^{\circ} \mathrm{C}$ (chloroform/heptane) (lit. ${ }^{10} 158{ }^{\circ} \mathrm{C}$, lit. ${ }^{11} 144-145{ }^{\circ} \mathrm{C}$ ). Ethyl 1-(4-chlorophenyl)-1H-1,2,4-triazole-3-carboxylate (3b). (Z)-Ethyl 2-amino-2-[2-(4chlorophenyl)hydrazono]acetate $(1 \mathrm{n}, 2.4 \mathrm{~g}, 10 \mathrm{mmol})$, formaldehyde $(37 \%, 1.5 \mathrm{~mL}, 20 \mathrm{mmol})$ and $p$-toluenesulfonic acid $(0.1 \mathrm{~g})$ were refluxed in ethanol (ca. $50 \mathrm{~mL})$ for about $7 \mathrm{~h}$ until starting amidrazone was converted completely. The mixture was cooled to room temperature and the solvent was evaporated. The solid product was collected and recrystallized from ethanol giving white crystals $\mathbf{3 b}(0.6 \mathrm{~g}, 24 \%)$; mp $135-136^{\circ} \mathrm{C}$ (ethanol) (lit. ${ }^{12} 121^{\circ} \mathrm{C}$ ).

Ethyl 1-(4-chlorophenyl)-5-methyl-1H-1,2,4-triazole-3-carboxylate (3c). Ethyl 2-amino-2-(4chlorophenyl)hydrazonoacetate $1 \mathrm{n}(2.4 \mathrm{~g}, 10 \mathrm{mmol})$, acetaldehyde $(1.1 \mathrm{~mL}, 20 \mathrm{mmol})$ and $p$ toluenesulfonic acid $(0.1 \mathrm{~g})$ were refluxed in ethanol (ca. $50 \mathrm{~mL}$ ) until the amidrazone was completely consumed. The mixture was cooled to room temperature and the solvent was evaporated. The solid product was collected and recrystallized from 2-propanol giving white crystals 3c (0.4 g, 15\%); mp 115-117 ${ }^{\circ} \mathrm{C}$ (2-propanol) (lit. ${ }^{13} 113-114.5^{\circ} \mathrm{C}$ ).

(E)-2-(2-Methyl-2-phenylhydrazono)- $N$-phenyl-2-(piperidin-1-yl)acetamide (7). A solution of 2-anilino- $N$-methyl-2-oxo- $N$-phenylethanehydrazonoyl chloride 6 (2.8 g, $10 \mathrm{mmol})$ in dioxane (ca. $40 \mathrm{~mL}$ ) was added dropwise to piperidine $(2.0 \mathrm{~mL}, 20 \mathrm{mmol})$ in a few $\mathrm{mL}$ dioxane. After stirring at $40-45^{\circ} \mathrm{C}$ for at least $12 \mathrm{~h}$ the mixture was poured into cold water $(150 \mathrm{~mL})$. The solid was collected, washed with water and dried. Recrystallization from heptane gave white crystals 7 (2.3 g, 68\%); mp 158-160 ${ }^{\circ} \mathrm{C}$ (heptane). ${ }^{1} \mathrm{H}$ NMR (400 MHz, DMSO- $\left.d_{6}, \mathrm{Me}_{4} \mathrm{Si}\right): \delta 10.36(1 \mathrm{H}, \mathrm{s}$, CONH), 6.70-7.55 (10H, Ph), $3.51\left(4 \mathrm{H}, \mathrm{s}, 2 \mathrm{CH}_{2}\right), 2.92(3 \mathrm{H}, \mathrm{s}, \mathrm{Me}), 1.68\left(6 \mathrm{H}, \mathrm{s}, 3 \mathrm{CH}_{2}\right) .{ }^{13} \mathrm{C}$ NMR (100 MHz, DMSO- $\left.d_{6}, \mathrm{Me}_{4} \mathrm{Si}\right): \delta 115.2-138.1$ (12C, Ph), $46.0(1 \mathrm{C}, \mathrm{Me}), 23.9\left(1 \mathrm{C}, \mathrm{CH}_{2}\right)$, $24.9\left(2 \mathrm{C} ; 2 \mathrm{CH}_{2}\right), 42.3\left(2 \mathrm{C}, 2 \mathrm{CH}_{2}\right), 152.5(1 \mathrm{C}, \mathrm{C}=\mathrm{N}), 162.3(1 \mathrm{C}, \mathrm{C}=\mathrm{O}) . \mathrm{EI}-\mathrm{MS}: \mathrm{m} / z(\%) 336(80$, $\mathrm{M}^{+}$), 84 (100). Anal. calcd. for $\mathrm{C}_{20} \mathrm{H}_{24} \mathrm{~N}_{4} \mathrm{O}$ : C, 71.40; H, 7.19; N, 16.65. Found: C, 71.08; H, $7.21 ; \mathrm{N}, 16.39$.

${ }^{1} \mathrm{H}$ NOE experiment (DMSO-d $d_{6}$ ): Irradiation at $\delta 2.92(\mathrm{Me}), \mathrm{NOE}$ at $\delta 6.84(2 \mathrm{H}, \mathrm{Ph}-\mathrm{H}$ in ortho position of hydrazonophenyl), at $\delta 7.54(2 \mathrm{H}, \mathrm{Ph}-\mathrm{H}$ in ortho position of anilidophenyl), and at $\delta$ $10.36(\mathrm{CONH})$.

4-(2-Chlorophenyl)-2-phenyl-6-(piperidin-1-yl)-3,4-dihydro-1,2,4-triazin-5(2H)-one (8). (Z)$N$-(2-Chlorophenyl)-2-(2-phenylhydrazono)-2-(piperidin-1-yl)acetamide (1i, $3.6 \mathrm{~g}, 10 \mathrm{mmol}$ ), a $37 \%$-solution of formaldehyde $(1.5 \mathrm{~mL}, 20 \mathrm{mmol})$ and $p$-toluenesulfonic acid $(0.1 \mathrm{~g})$ were refluxed in ethanol (ca. $50 \mathrm{~mL}$ ) until all amidrazone was completely consumed. The mixture was cooled to room temperature and the solvent was evaporated. The solid product was collected and recrystallized from methanol to yield yellow crystals 8 (3.6 g, 92\%); mp 128-130 ${ }^{\circ} \mathrm{C}$. ${ }^{1} \mathrm{H}$ NMR (400 MHz, DMSO- $\left.d_{6}, \mathrm{Me}_{4} \mathrm{Si}\right): \delta$ 6.9-7.6 (9H, Ph), $1.60\left(6 \mathrm{H}, \mathrm{s}, 3 \mathrm{CH}_{2}\right), 3.25\left(4 \mathrm{H}, \mathrm{s}, 2 \mathrm{CH}_{2}\right), 5.22$ $\left(2 \mathrm{H}, \mathrm{NCH}_{2} \mathrm{~N}\right) .{ }^{13} \mathrm{C} \mathrm{NMR}\left(100 \mathrm{MHz}, \mathrm{DMSO}-d_{6}, \mathrm{Me}_{4} \mathrm{Si}\right): \delta$ 114.7-145.0 (12C, Ph), $24.0(1 \mathrm{C}$, $\left.\mathrm{CH}_{2}\right), 24.7\left(2 \mathrm{C}, 2 \mathrm{CH}_{2}\right), 48.2\left(2 \mathrm{C}, 2 \mathrm{CH}_{2}\right), 63.2\left(1 \mathrm{C}, \mathrm{NCH}_{2} \mathrm{~N}\right), 147.2(1 \mathrm{C}, \mathrm{C}=\mathrm{N}), 152.5(1 \mathrm{C}, \mathrm{C}=\mathrm{O})$. EI-MS: $m / z(\%) 368\left(100, \mathrm{M}^{+}\right)$. Anal. calcd. for $\mathrm{C}_{20} \mathrm{H}_{21} \mathrm{ClN}_{4} \mathrm{O} \mathrm{C}, 65.12 ; \mathrm{H}, 5.74 ; \mathrm{N}, 15.19 ; \mathrm{Cl}$ 9.61. Found: C, 64.93; H, 5.64; N, 15.04; Cl, 9.20.

HMBC experiment (DMSO- $\left.d_{6}\right)$ : Correlation of $2 \mathrm{H}\left(\mathrm{CH}_{2}\right.$ of triazinone) $\delta_{\mathrm{H}} 5.22$ with $\mathrm{C}=\mathrm{O} \delta_{\mathrm{C}}$ 
152.5, with C-Ph of hydrazonophenyl $\delta_{\mathrm{C}} 145.0$ and with C-Ph of anilidophenyl $\delta_{\mathrm{C}} 136.7$.

Cyclic voltammetry. Acetonitrile (Acros Organics) was of HPLC grade. Lithium perchlorate (Fluka Chemical) was used as supporting electrolyte at $0.05 \mathrm{M}$ concentration in all experiments. Ferrocene (Merck KgaA, Darmstadt) was employed as inner standard at $0.01 \mathrm{M}$ concentration throughout. Solutions were deoxygenated with 99,999\% argon for $5 \mathrm{~min}$ before the start of the experiments. A platinum microelectrode (Bioanalytical Systems, diameter: $0.01 \mathrm{~mm}$ ) and a platinum macroelectrode (diameter: $0.15 \mathrm{~mm}$ ) were alternately used as working electrodes, together with a platinum wire auxiliary electrode and a $\mathrm{Ag} / \mathrm{AgCl}$ (satd) reference electrode. At the beginning of each measurement the working electrodes had to be polished with aluminium oxide abrasive (grit size: $0.3 \mu \mathrm{m}$ ) to get comparable results. The cyclic voltammograms of the samples (conc. approx. $1 \mathrm{mmol}$ in acetonitrile) were recorded at room temperature and related to Ferrocene.

Microcoulometry. $54 \mu \mathrm{mol}$ of $\mathbf{2 d}$ were dissolved in $50 \mathrm{ml}$ electrolyte $(0.1 \mathrm{M}$ lithium perchlorate in acetonitrile) and placed in a small three-compartment-cell. The area of the platinum sheet used as working electrode was $1 \mathrm{~cm}^{2}$. All further instrumental parameters were the same as in the cyclovoltammetric experiment. The potential was adjusted to 700 $\mathrm{mV}$ and the current was registrated against the time. During the electrolysis the color of the solution changed from yellow to deep blue. When the current dropped down to $0.1 \mathrm{~mA}$ the electrolysis was finished and the charge calculated by integration of the current along the time.

Quantum chemical calculations. Molecular and electronic structures of radical cations and their neutral molecules were investigated by the density functional theory (DFT) hybrid B3LYP method with standard 6-31G(d) basis set. ${ }^{6}$

\section{Acknowledgements}

Prof. Andrea Sinz is acknowledged for proof-reading the manuscript.

\section{References}

1. (a) Aly, A. A.; Nour-El-Din A. M. ARKIVOC 2008, (i), 153. (b) Aly, A. A.; Gomaa, M. A.M.; Nour-El-Din A. M.; Fahmy M. S. ARKIVOC 2007, (xvi), 41.

2. Mamolo, M. G.; Zampieri, D.; Falagiani, V.; Vio, L.; Fermeglia, M.; Ferrone, M.; Pricl, S.; Banfi, E.; Scialino, G. ARKIVOC 2004, (v), 231. 
3. (a) Rathbone, D. L.; Parker, K. J.; Coleman, M. D.; Lambert, P. A.; Billington, D. C. Bioorg. Med. Chem. Let. 2006, 16, 879. (b) Coleman, M. D.; Khan, N.; Welton, G.; Lambert, P. A.; Tims, K. J.; Rathbone, D. L. Environ. Toxicol. Pharmacol. 2004, 17, 143.

4. (a) Clemens, F.; Drutkowski, G.; Wiese, M.; Frohberg, P. Biochimica et Biophysica Acta 2001, 1549, 88. (b) Frohberg, P.; Kupfer, C.; Stenger, P.; Baumeister, U.; Nuhn, P. Arch. Pharm. 1995, 328, 505.

5. (a) Frohberg, P.; Wagner, C.; Meier, R.; Sippl, W. Tetrahedron 2006, 62, 6050. (b) Drutkowski, G.; Donner, C.; Schulze, I.; Frohberg, P. Tetrahedron 2002, 58, 5317.

6. Pople, J. A. Gaussian98, 1998, Gaussian Inc. Pittsburg, PA.

7. Hicks, R. G. Org. Biomol. Chem. 2007, 5, 1321.

8. (a) Hegarty, A. F.; Rigopoulos, P.; Rowe, J. E. Aust. J. Chem. 1987, 40, 1777. (b) Rowe, J. E.; Lee, K. Aust. J. Chem. 1997, 50, 849. (c) Sergutina, V. P.; Zelenin, K. N.; Khrustalev, V. A. Zh. Org. Khim. 1978, 14, 622; Chem. Abstr. 1978, 89, 59627. (d) Khrustalev, V. A.; Zelenin, K. N.; Sergutina, V. P. Zh. Org. Khim. 1979, 15, 2280; Chem. Abstr. 1979, 92, 180607.

9. Frohberg, P.; Drutkowski, G.; Wagner, C. Eur. J. Org. Chem. 2002, 10, 1654.

10. Buelow, C.; Neber, P. Ber. Dtsch. Chem. Ges. 1913, 46, 2041.

11. Bowack D. A.; Lapworth, A. J. Chem. Soc. 1905, 87, 1859.

12. Eckert, U.; Robl, C.; Fehlhammer, W. P. Organometallics 1993, 12, 3241.

13. Browne, E. J.; Polya, J. B. J. Chem. Soc. 1962, 5149. 